\title{
Is the global rise of asthma an early impact of anthropogenic climate change?*
}

Paul John Beggs 1

Hilary Jane Bambrick 2

\author{
Será o crescimento mundial de incidência \\ da asma um impacto antecipado de mudanças \\ climáticas antropogênicas?
}

* This article was originally published by the journal Environmental Health Perspectives (113:915-919 (2005). doi:10.1289/ ehp.7724 available via http://dx.doi.org/ [Online 20 April 2005] and is part of the scientific collaboration between Rev C S Col and EHP.

1 Department of Physical Geography, Division of Environmental and Life Sciences, Macquarie University. New South Wales 2109, Australia. paul.beggs@mq.edu.au 2 National Centre for Epidemiology and Population Health, Australian National University.
Abstract The increase in asthma incidence, prevalence, and morbidity over recent decades presents a significant challenge to public health. Pollen is an important trigger of some types of asthma, and both pollen quantity and season depend on climatic and meteorological variables. Over the same period as the global rise in asth$m a$, there have been considerable increases in atmospheric carbon dioxide concentration and global average surface temperature. We hypothesize anthropogenic climate change as a plausible contributor to the rise in asthma. Greater concentrations of carbon dioxide and higher temperatures may increase pollen quantity and induce longer pollen seasons. Pollen allergenicity can also increase as a result of these changes in climate. Exposure in early life to a more allergenic environment may also provoke the development of other atopic conditions, such as eczema and allergic rhinitis. Although the etiology of asthma is complex, the recent global rise in asthma could be an early health effect of anthropogenic climate change.

Key words Aeroallergens, Anthropogenic climate change, Asthma, Carbon dioxide
Resumo O crescimento na incidência, prevalência e morbidade da asma durante as recentes décadas representa importante desafio para a saúde pública. Pólen é um importante desencadeador de alguns tipos de asma e tanto a sua quantidade como as especificidades das estações em que eles mais se disseminam dependem de variáveis climáticas e meteorológicas. No mesmo período em que se observa o incremento na incidência da asma houve considerável crescimento de concentração de dióxido de carbono na atmosfera e aumento da média de temperatura da superfície da terra. Nossa hipótese é a de que as mudanças antropogênicas do clima constituem um fator plausivel para o incremento da incidência da asma. Maiores concentrações de dióxido de carbono e elevadas temperaturas podem aumentar a quantidade de pólen e induzir o aumento de variações climáticas que facilitam sua dispersão. Alergias a pólen podem aumentar como resultado de mudanças climáticas. Exposição precoce a ambientes que predisponham a alergias também podem provocar o desenvolvimento de condições atópicas, como eczema e rinite alérgica. Embora a etiologia da asma seja complexa, o recente incremento de sintomas de asma em nível global pode significar um dos antecipados efeitos sobre a saúde, de mudanças climáticas antropogênicas.

Palavras-chave Alergias, Alergias a pólen, $\mathrm{Mu-}$ danças climáticas antropogênicas, Asma, Dióxido de carbono 


\section{Global trends in asthma}

Although asthma patterns vary throughout the world, considerable increases in both the prevalence of asthma and its severity have occurred globally over recent decades $1,2,3$. Because this rise has been far too rapid to implicate any genetic basis for change, various environmental factors and lifestyle factors have been proposed, and most recently the "hygiene hypothesis" has been explored extensively 1 as an explanation for increased asthma prevalence. In this commentary, we propose an additional explanation: that a significant proportion of the increase in both asthma prevalence and its severity is the result of anthropogenic climate change.

Evidence for the global increase in the burden of asthma has come from studies of incidence, prevalence, and morbidity. Asthma prevalence appears to have increased since the early $1960 s^{4}$, with the rise in asthma prevalence occurring among both children and adults 5 and in a wide range of countries with differing lifestyles 4 . Over a similar period, the prevalence of other atopic disorders, such as allergic rhinitis, atopic eczema, and urticaria, has also increased, once again throughout the world 1,4 .

Studies of hospital admissions and surveys of symptoms of severe asthma indicate increased asthma morbidity since the early $1960 s^{4,6,7}$, particularly in young children 4 . This increase in asthma morbidity can not be completely explained by an increase in readmissions, diagnostic transfer from related disease categories, or changes in medical practicet.

In contrast with the overall trend of a rise in asthma over several decades, a few studies have reported an apparent leveling off or even a decline of asthma in recent years. Robertson et al. 8 reported a $26 \%$ decline in the prevalence of reported wheeze between surveys conducted in 1993 and 2002 in Melbourne, Australia, among children 6-7 years of age. The study also found a reduction in emergency department visits and hospital admissions, which may be due at least partly to improved asthma management. Interestingly, the same survey found a $31 \%$ increase in allergic rhinitis, which is commonly linked to asthma, a $55 \%$ increase in eczema, and an increase in those taking regular steroid medication among those with frequent wheeze. A United Kingdom study comparing reported wheeze in 12- to 14-year-olds in 1995 and $2002^{9}$ also found a decrease in reported prevalence of wheezing, and a decline in fre- quency and severity of attacks, but the proportion reporting that they had ever had asthma increased by $26 \%$ (allergic rhinitis by $8 \%$ ). Both of these studies infer trends from only two time points. Although this is not uncommon where good data are scarce, care is required in their interpretation.

Fleming et al. 10 examined weekly general practitioner returns in England and Wales between 1989 and 1998. After a peak in 1993-1994, there appears to have been a gradual decline in new asthma presentations to general practitioners, which is mirrored by a similar decline in acute bronchitis presentations. This study benefits from having continuous (weekly) data available over a decade rather than two points in time. Nevertheless, the observed decline occurred only over 4-5 years, which is a relatively short time in a half-century of overall observed increase. Recent milder winters (perhaps due to climate change) may have contributed to this decline, although some decrease was observed in other seasons ${ }^{10}$. Furthermore, although new presentations declined, there was no reduction in the use of bronchodilators, and the use of inhaled steroids increased during the same period.

If the plateaus in asthma prevalence recently observed in these studies are real and prove to be sustained, this could be an indication that saturation point has been reached in some locations. With heritability estimated to be up to $75 \%$, there is likely to be some genetic component in the etiology of asthma. Recent plateaus may reflect that the proportion of the population genetically more susceptible to developing asthma may already have done so. Further, several co-occurring factors may promote a decline in asthma, exerting perhaps converse pressure protecting against asthma - for instance, increases in the number of children attending child care.

There has been a sustained focus on identifying the causative environmental factors of the overall trend to increasing asthma prevalence and morbidity 11 ; however, these environmental factors are still unknown ${ }^{12}$. Some environmental factors previously proposed to explain the increased global prevalence of asthma include increased air pollution 13,14 , changed diet $15,16,17,18$, and increased prevalence of maternal smoking19, 20. Further potential explanatory factors come under the hygiene hypothesis, which proposes that greater risk of atopy results from altered challenges to the immune 
system in early life - particularly reduced infections - and the consequent development of a bias towards T-helper type 2 immune response over T-helper type 121 . Specific factors proposed under the hygiene hypothesis include changed immunization practices 22,23 , changed living conditions and increased exposure to indoor allergens 24 , increased use of antibiotics 25 , 26,27 , and reduced exposure to endotoxins 28,29 , 30. These factors may explain some of the increase in predisposition to atopy, but any effects on asthma prevalence and morbidity could be compounded by changing pollen profiles. Furthermore, studies examining the hygiene hypothesis have not been entirely consistent, with some showing no effects of these exposures on subsequent development of asthma ${ }^{31}$. Inconsistencies may result from different social trends that alter exposures in more than one direction. Although some trends may have reduced potentially protective exposures (increased urbanization, reduced family size, and increased maternal work stress during pregnancy), others (e.g., greater use of formal child care) may increase the protective exposures.

Climate change provides an additional plausible explanation for both increasing asthma susceptibility and increasing severity observed over several decades. There are many types of asthma, and we seek to explain only the component of the increase that is allergic asthma, particularly pollen-induced asthma. This is likely to be a significant proportion of asthma cases. For example, Grossman ${ }^{32}$ suggests that up to $78 \%$ of people with asthma also suffer from allergic rhinitis. Furthermore, although the hypothesis that trends in air pollution have been major determinants for the rise in prevalence of asthma and allergic disease in recent decades is now generally disproved 33,34 , air pollution is likely to have its own effects on pollen production.

\section{Anthropogenic climate change}

Human activities have led to increases in atmospheric carbon dioxide concentration and consequent changes in climate [Intergovernmental Panel on Climate Change (IPCC) 2001] 36. Before the advent of the Industrial Era (circa 1750), atmospheric $\mathrm{CO}_{2}$ concentration had been $280 \pm$ 10 ppm for several thousand years ${ }^{37}$. It has risen since then, with the mean annual concentration recorded at the Mauna Loa Observatory in
Hawaii in 2002 at 373 ppm $^{38}$. The increase over this period has not been linear. The Mauna Loa data show an $18 \%$ increase in the mean annual concentration since the start of the records in 1959 , when it was $316 \mathrm{ppm}^{38}$. This suggests that approximately two-thirds of the increase in atmospheric $\mathrm{CO}_{2}$ concentration since the Industrial Era has occurred over the last 50 years or so. These increases in $\mathrm{CO}_{2}$ and other greenhouse gases have enhanced the greenhouse effect, resulting in global warming and other changes to climate. The global average surface temperature has increased by $0.6 \pm$ $0.2^{\circ} \mathrm{C}$ since the late 19 th century, with much of this warming occurring during two periods, 1910-1945 and 1976-200039. The IPCC has stated that "most of the observed warming over the last 50 years is likely to have been due to the increase in greenhouse gas concentrations" 39. In addition to these already observed changes, human influences will continue to change atmospheric composition (including increasing $\mathrm{CO}_{2}$ ) and climate throughout the 21 st century and beyond 39 .

Some researchers have proposed that global climate change is likely to have an effect in the future on asthma ${ }^{40}$. We suggest that some of the observed increase in asthma could be due to climate change that has already occurred.

\section{Elevated $\mathrm{CO}_{2}$ and climate change impacts on pollen}

The balance of evidence strongly suggests that a significant impact of climate change is already discernible in animal and plant populations 41 , as well as communities and ecosystems ${ }^{42}$. For example, analysis of data from the International Phenological Gardens in Europe (a network of sites covering $69-42^{\circ} \mathrm{N}$ and $10^{\circ}$ $\mathrm{W}-27^{\circ} \mathrm{E}$ ) has shown that spring events, such as flowering, have advanced by 6 days, and that autumn events have been delayed by 4.8 days, compared with the early 1960s 43 .

There is now also considerable evidence of impacts of climate change on aeroallergens, particularly pollen ${ }^{44}$. First, it appears that plants produce a greater quantity of pollen under these changed climatic conditions. Experimental studies have found substantial increases in pollen production resulting from exposure to increased $\mathrm{CO}_{2}$ concentration, including from levels equivalent to preindustrial $\mathrm{CO}_{2}$ to current concentrations 45,46 . Other studies have exam- 
ined trends in pollen amount over the latter decades of the 1900s and found increases to be associated with local rises in temperature 47,48 . Second, there is some evidence of significantly stronger allergenicity in pollen from trees grown at increased temperatures 49,50 . The association between changes in temperature and pollen allergenicity is under investigation and is likely to vary across plant species. Third, changes in climate appear to have altered the temporal and spatial distribution of pollen. For example, some studies have found that trends toward earlier pollen seasons are associated with local warming over the latter decades of the $1900 \mathrm{~s}^{51}$, 52 , and recent reports have concluded that the duration of the pollen season is extended in some species ${ }^{53}$. Finally, several studies have examined other attributes of allergenic plants, which have also been responsive to $\mathrm{CO}_{2}$ concentration and/or temperature increases ${ }^{54,55}$. These latter studies provide indirect evidence of impacts of climate change on pollen aeroallergens.

\section{Impacts of climate change on asthma}

The links between aeroallergens and allergic diseases such as asthma are well established12, 56. It is feasible that faster plant growth, earlier plant maturity, and longer growing season, plus earlier pollen season, increased season duration, and increases in both pollen quantity and allergenicity have already had an impact on asthma, reflected in the global rise in asthma prevalence and increased severity of episodes.

Climate change might readily explain more than just increased morbidity among those with the condition; it could also be a candidate for increasing the initial susceptibility to asthma and hence the prevalence of the condition. Exposure to allergens in infancy is thought to sensitize individuals to asthma ${ }^{3}$ and other atopic conditions such as eczema and allergic rhinitis. Björkstén and Suoniemi 57 found, for example, that exposure to more intense pollen seasons in early infancy increased the likelihood of later development of allergy. Therefore, increases in pollen quantity and extended pollen seasons due to climate change may lead to both an increase in the development of the condition and greater morbidity among those who have it (Figure 1).

Although future impacts of climate change on human health have received considerable and increasing amounts of attention since the mid-1990s, few studies have documented human health impacts already evident. A study of the El Niño - Southern Oscillation and cholera in Bangladesh from around 1900 to 2001 may provide the first evidence that warming trends over the last century are already affecting human health 58, 59. The World Health Organization (WHO) has identified climate change as a major environmental risk to health 60 . The WHO estimated that climate change was responsible for approximately $2.4 \%$ of diarrhea cases (worldwide), $6 \%$ of malaria cases (in some middle-income countries), and $7 \%$ of dengue fever cases (in some industrialized countries) in 2000. In total, climate change was estimated to be responsible for $0.3 \%$ of deaths and $0.4 \%$ of disability-adjusted life years 60 .

The potential for future climate change to have an impact on asthma and other allergic diseases has been recognized for some time ${ }^{36}$, 61 , mostly a result of the well-established link between climate and many aeroallergens and aeroallergen-producing organisms, on the one hand, and air pollution on the other. However, that climate change could alter the burden of noncommunicable diseases such as asthma has received far less attention than have potential impacts on infectious vector-borne and diarrheal diseases.

It is somewhat easier to establish direct links between changing climate and the burden of these infectious diseases, where etiology is fairly well established. In contrast, the etiology of asthma is complex and not well understood. The complexity of asthma and the greater urgency that tends to be ascribed to communicable disease may explain why little attention has to date been paid to the effects of climate change on asthma. Furthermore, that climate change impacts on asthma may already be evident has previously not been explored.

Recent urban-rural comparisons in asthma and pollen provide a useful analogy to the global climate change hypothesis presented here. Using the existing $\mathrm{CO}_{2}$ and temperature gradient between rural and urban areas, Ziska et al. 62 showed that the higher $\mathrm{CO}_{2}$ concentrations and air temperatures of urban areas were associated with differences in ragweed (Ambrosia artemisiifolia). The urban plants of this established allergy-inducing species produced significantly more pollen than the plants in rural areas. Greater aeroallergen levels in urban areas may have contributed to the higher childhood 
Figure 1

Schematic diagram of the relationship between global climate change and the rise in asthma prevalence and severity, via impacts of climate change on plant and pollen attributes.

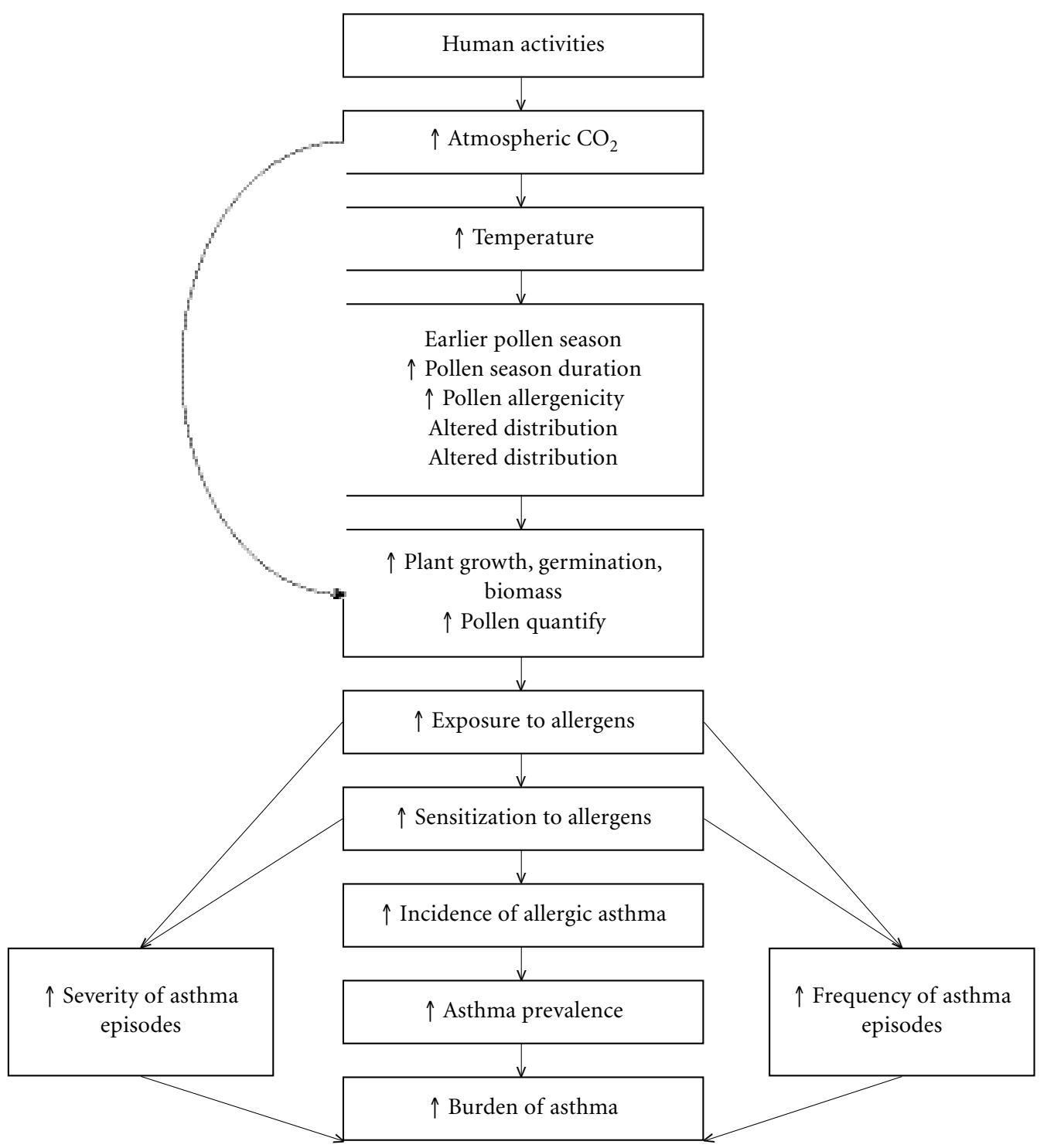

asthma prevalence of urban areas. These local effects provide some support for pollen quantity as a significant contributor to asthma prevalence. Weinberg63 confirms the urban-rural differences in childhood asthma prevalence, but has shown a much narrower gap, suggesting an accelerated rise in aeroallergen level in rural areas associated with global increases in atmospheric $\mathrm{CO}_{2}$ concentration and temperature.

\section{Conclusions}

Seeking evidence of early effects of climate change on human health has been identified as a major challenge for scientists studying climate change and health 64 . The detection of health effects of climate change is necessary as evidence underpinning national and international policies relating to measures to protect public health, such as the mitigation of greenhouse 
gas emissions 65 and, given that we are already committed to some climate change, strategies for adaptation.

Asthma is etiologically complex, with numerous contributing factors and interactive effects within the causal web, many of which are modified by climate. The changing global climate compounds this complexity. There is some evidence to suggest that asthma prevalence but not severity - may have plateaued in some countries very recently. However, it is too early to determine whether this leveling off will be sustained. Either way, the hypothesis that the global rise of asthma is an early impact of anthropogenic climate change still stands. Further, this climate change hypothesis does not conflict with the hygiene hypothesis, but adds an additional possibility to the mix; each may contribute to the observed rise in asthma.

\section{Collaborations}

PJ Beggs and HJ Bambrick have participated to an equal extent in the preparation of the present article.

\section{Acknowledgement}

Many thanks to N. Pearce for providing asthma prevalence data, and to the National Centre for Epidemiology and Population Health review group for their very helpful comments: C. Blumer, R. D’Souza, K. Glass, J. Harris, R. Lucas, L. Strazdins, and R. Woodruff. The authors declare they have no competing financial interests.
Specific hypotheses relating asthma to climate change must be developed and rigorously tested. To tease out the climate change-asthma relationships, it will be necessary to distinguish between an increase in the prevalence of asthma and an increase in the morbidity, incidence, and burden of disease, because climate change may contribute to both a rise in prevalence and increased severity. Furthermore, because of the variation in prevalence throughout the world, studies will need to address patterns at national, subnational, and local scales. Proof that recent climate change has had an adverse impact on asthma will come only from the accumulation of studies focused on this topic. For comparisons of the impact of global climate change between areas and over time, international definitions of asthma, such as that developed by the International Study of Asthma and Allergies in Childhood66, should be used to establish baselines and to measure trends.

\section{References}

1. Bach J-F. The effect of infections on susceptibility to autoimmune and allergic diseases. N Engl J Med 2002; 347:911-20.

2. Isolauri E, Huurre A, Salminen S, Impivaara O. The allergy epidemic extends beyond the past few decades. Clin Exp Allergy 2004; 34:1007-10.

3. Pearce N, Douwes J, Beasley R. The rise and rise of asthma: a new paradigm for the new millennium? J Epidemiol Biostat 2000; 5:5-16.

4. Beasley R. The burden of asthma with specific reference to the United States. J Allergy Clin Immunol 2002; 109(suppl):S482-S489; [Online 19 September 2002].

5. Beasley R, Crane J, Lai CKW, Pearce N. Prevalence and etiology of asthma. J Allergy Clin Immunol 2000; 105(suppl):S466-S472.

6. Kao C-C, See L-C, Yan D-C, Ou L-S, Huang J-L. Time trends and seasonal variations in hospital admissions for childhood asthma in Taiwan from 1990 to 1998. Asian Pac J Allergy Immunol 2001; 19:63-8. 
7. Kerr RA. Climate prediction. Signs of success in forecasting El Niño. Science 2002; 297:497, 499.

8. Robertson CF, Roberts MF, Kappers JH. Asthma prevalence in Melbourne schoolchildren: have we reached the peak? Med J Aust 2004; 180:273-6.

9. Anderson HR, Ruggles R, Strachan DP, Austin JB, Burr M, Jeffs D, et al. Trends in prevalence of symptoms of asthma, hay fever, and eczema in 12-14 year olds in the British Isles, 1995-2002: questionnaire survey. Br Med J 2004; 328:1052-3; [Online 17 March 2004].

10. Fleming DM, Sunderland R, Cross KW, Ross AM. Declining incidence of episodes of asthma: a study of trends in new episodes presenting to general practitioners in the period 1989-98. Thorax 2000; 55:657-61.

11. Sunyer J, Antó JM, Tobias A, Burney P, for the European Community Respiratory Health Study (ECRHS). Generational increase of self-reported first attack of asthma in fifteen industrialized countries. Eur Respir J 1999; 14:885-91.

12. Nolte H, Backer V, Porsbjerg C. Environmental factors as a cause for the increase in allergic disease. Ann Allergy Asthma Immunol 2001; 87(6 suppl 3):711.

13. D’Amato G, Liccardi G, D'Amato M. Environmental risk factors (outdoor air pollution and climatic changes) and increased trend of respiratory allergy. J Investig Allergol Clin Immunol 2000; 10:123-8.

14. Rios JLM, Boechat JL, Sant'Anna CC, França AT. Atmospheric pollution and the prevalence of asthma: study among schoolchildren of 2 areas in Rio de Janeiro, Brazil. Ann Allergy Asthma Immunol 2004; 92:629-34.

15. Ellwood P, Asher MI, Björkstén B, Burr M, Pearce N, Robertson $\mathrm{CF}$, et al. Diet and asthma, allergic rhinoconjunctivitis and atopic eczema symptom prevalence: an ecological analysis of the International Study of Asthma and Allergies in Childhood (ISAAC) data. Eur Respir J 2001; 17:436-43.

16. Hijazi N, Abalkhail B, Seaton A. Diet and childhood asthma in a society in transition: a study in urban and rural Saudi Arabia. Thorax 2000; 55:775-9.

17. Seaton A, Devereux G. Diet, infection and wheezy illness: lessons from adults. Pediatr Allergy Immunol 2000; 11(suppl 13):37-40.

18. Sigurs N, Hattevig G, Kjellman B. Maternal avoidance of eggs, cow's milk, and fish during lactation: effect on allergic manifestations, skin-prick tests, and specific IgE antibodies in children at age 4 years. Pediatrics 1992; 89:735-9.

19. Lødrup Carlsen KC. 2002. The Environment and Childhood Asthma (ECA) study in Oslo: ECA-1 and ECA-2. Pediatr Allergy Immunol 2002; 13(suppl):29-31.

20. Ulrik CS, Backer V. Atopy in Danish children and adolescents: results from a longitudinal population study. Ann Allergy Asthma Immunol 2000; 85:293-7.

21. Strachan DP. Family size, infection and atopy: the first decade of the "hygiene hypothesis." Thorax 2000; 55(suppl 1):S2-S10.

22. Portengen L, Sigsgaard T, Omland Ø, Hjort C, Heederik D, Doekes G. Low prevalence of atopy in young Danish farmers and farming students born and raised on a farm. Clin Exp Allergy 2002; 32:247-53.

23. von Mutius $\mathrm{E}$. The rising trends in asthma and aller- gic disease. Clin Exp Allergy 1998; 28(suppl):45-9.

24. Kaiser HB. Risk factors in allergy/asthma. Allergy Asthma Proc 2004; 25:7-10.

25. Cohet C, Cheng S, MacDonald C, Baker M, Foliaki S, Huntington N, et al. 2004. Infections, medication use, and the prevalence of symptoms of asthma, rhinitis, and eczema in childhood. J Epidemiol Community Health 2004; 58:852-7.

26. Droste JHJ, Wieringa MH, Weyler JJ, Nelen VJ, Vermeire PA, Van Bever HP. Does the use of antibiotics in early childhood increase the risk of asthma and allergic disease? Clin Exp Allergy 2000; 30:1547-53.

27. Foliaki S, Nielsen SK, Björkstén B, von Mutius E, Cheng S, Pearce N, et al. Antibiotic sales and the prevalence of symptoms of asthma, rhinitis, and eczema: The International Study of Asthma and Allergies in Childhood (ISAAC). Int J Epidemiol 2004; 33:558-63; [Online 11 March 2004].

28. Eder W, von Mutius E. Hygiene hypothesis and endotoxin: what is the evidence? Curr Opin Allergy Clin Immunol 2004; 4:113-7.

29. Eduard W, Douwes J, Omenaas E, Heederik D. Do farming exposures cause or prevent asthma? Results from a study of adult Norwegian farmers. Thorax 2004; 59:381-6.

30. Gehring U, Bolte G, Borte M, Bischof W, Fahlbusch $\mathrm{B}$, Wichmann H-E, et al. Exposure to endotoxin decreases the risk of atopic eczema in infancy: a cohort study. J Allergy Clin Immunol 2001; 108:847-54; [Online 9 May 2002].

31. von Hertzen LC, Haahtela T. Asthma and atopy - the price of affluence? Allergy 2004; 59:124-37.

32. Grossman J. One airway, one disease. Chest 1997; 111(suppl 2):11S-16S.

33. Charpin D, Pascal L, Birnbaum J, Armengaud A, Sambuc R, Lanteaume A, et al. Gaseous air pollution and atopy. Clin Exp Allergy 1999; 29:1474-80.

34. Strachan DP. The role of environmental factors in asthma. Br Med Bull 2000; 56:865-82.

35. D'Amato G, Liccardi G, D'Amato M, Cazzola M. The role of outdoor air pollution and climatic changes on the rising trends in respiratory allergy. Respir Med 2001; 95:606-11; [Online 15 May 2002].

36. IPCC. Climate Change 2001: Impacts, Adaptation, and Vulnerability. Contribution of Working Group II to the Third Assessment Report of the Intergovernmental Panel on Climate Change (McCarthy JJ, Canziani OF, Leary NA, Dokken DJ, White KS, eds). Cambridge, UK: Cambridge University Press; 2001.

37. Prentice IC, Farquhar GD, Fasham MJR, Goulden ML, Heimann M, Jaramillo VJ, et al. The carbon cycle and atmospheric carbon dioxide. In: Climate Change 2001: The Scientific Basis. Contribution of Working Group I to the Third Assessment Report of the Intergovernmental Panel on Climate Change (Houghton JT, Ding Y, Griggs DJ, Noguer M, van der Linden PJ, Dai X, et al., eds). Cambridge, UK: Cambridge University Press; 2001; p. 183-237.

38. Keeling CD, Whorf TP. 2003. Atmospheric Carbon Dioxide Record from Mauna Loa. Carbon Dioxide Information Analysis Center. Trends: A Compendium of Data on Global Change. Oak Ridge, TN: Carbon Dioxide Information Analysis Center, Oak Ridge National Laboratory. Available from: http://cdiac. ornl.gov/trends/co2/sio-mlo.htm [accessed 12 February 2004]. 
39. Albritton DL, Meira Filho LG, Cubasch U, Dai X, Ding Y, Griggs DJ, et al. Technical summary. In: Climate Change 2001: The Scientific Basis. Contribution of Working Group I to the Third Assessment Report of the Intergovernmental Panel on Climate Change (Houghton JT, Ding Y, Griggs DJ, Noguer M, van der Linden PJ, Dai X, et al., eds). Cambridge, UK: Cambridge University Press; 2001. p. 21-83.

40. Longstreth J. Anticipated public health consequences of global climate change. Environ Health Perspect 1991; 96:139-44.

41. Root TL, Price JT, Hall KR, Schneider SH, Rosenzweig C, Pounds JA. Fingerprints of global warming on wild animals and plants. Nature 2003; 421:57-60; [Online 2 January 2003].

42. Walther G-R, Post E, Convey P, Menzel A, Parmesan C, Beebee TJC, et al. Ecological responses to recent climate change. Nature 2002; 416:389-395; [Online 28 March 2002].

43. Menzel A, Fabian P. Growing season extended in Europe. Nature 1999; 397:659.

44. Beggs PJ. Impacts of climate change on aeroallergens: past and future. Clin Exp Allergy 2004; 34:150713; [Online October 2004].

45. Wayne P, Foster S, Connolly J, Bazzaz F, Epstein P. Production of allergenic pollen by ragweed (Ambrosia artemisiifolia L.) is increased in $\mathrm{CO}_{2}$-enriched atmospheres. Ann Allergy Asthma Immunol 2002; 88:279-82.

46. Ziska LH, Caulfield FA. 2000. Rising $\mathrm{CO}_{2}$ and pollen production of common ragweed (Ambrosia artemisiifolia), a known allergy-inducing species: implications for public health. Aust J Plant Physiol 2000; 27:893-8.

47. Corden JM, Millington WM. 2001. The long-term trends and seasonal variation of the aeroallergen $\mathrm{Al}$ ternaria in Derby, UK. Aerobiologia 2001; 17:127-36.

48. Spieksma FThM, Emberlin JC, Hjelmroos M, Jäger $\mathrm{S}$, Leuschner RM. Atmospheric birch (Betula) pollen in Europe: trends and fluctuations in annual quantities and the starting dates of the seasons. Grana 1995; 34:51-7.

49. Ahlholm JU, Helander ML, Savolainen J. Genetic and environmental factors affecting the allergenicity of birch (Betula pubescens ssp. czerepanovii [Orl.] Hämet-Ahti) pollen. Clin Exp Allergy 1998; 28:13848.

50. Hjelmroos M, Schumacher MJ, Van Hage-Hamsten M. Heterogeneity of pollen proteins within individual Betula pendula trees. Int Arch Allergy Immunol 1995; 108:368-76.

51. Emberlin J, Detandt M, Gehrig R, Jaeger S, Nolard $\mathrm{N}$, Rantio-Lehtimäki A. Responses in the start of Betula (birch) pollen seasons to recent changes in spring temperatures across Europe. Int J Biometeorol 2002; 46:159-70; [Online 26 July 2002].

52. Fitter AH, Fitter RSR. 2002. Rapid changes in flowering time in British plants. Science 2002; 296:168991.
53. Huynen M, Menne B. Phenology and Human Health: Allergic Disorders. Report of a WHO Meeting, Rome, Italy, 16-17 January 2003. Health and Global Environmental Change, Series No. 1 (EUR/03/5036791 and EUR/02/5036813). Geneva: World Health Organization; 2003.

54. Menzel A. Trends in phenological phases in Europe between 1951 and 1996. Int J Biometeorol 2000; 44:76-81.

55. Wulff RD, Alexander HM. Intraspecific variation in the response to $\mathrm{CO}_{2}$ enrichment in seeds and seedlings of Plantago lanceolata L. Oecologia 1985; 66:458-60.

56. Burge HA, Rogers CA. Outdoor allergens. Environ Health Perspect 2000; 108(suppl 4):653-9.

57. Björkstén F, Suoniemi I. 1981. Time and intensity of first pollen contacts and risk of subsequent pollen allergies. Acta Med Scand 1981; 209:299-303.

58. Patz JA. A human disease indicator for the effects of recent global climate change. Proc Natl Acad Sci USA 2002; 99:12506-12508; [Online 23 September 2002].

59. Rodó X, Pascual M, Fuchs G, Faruque ASG. ENSO and cholera: a nonstationary link related to climate change? Proc Natl Acad Sci USA 2002; 99:12901-6; [Online 12 September 2002].

60. World Health Organization. The World Health Report. Geneva: WHO; 2002.

61. Curson P. 1993. Climate and chronic respiratory disease in Sydney - the case of asthma. Climatic Change 1993; 25:405-20.

62. Ziska LH, Gebhard DE, Frenz DA, Faulkner S, Singer $\mathrm{BD}$, Straka JG. Cities as harbingers of climate change: common ragweed, urbanization, and public health. J Allergy Clin Immunol 2003; 111:290-5; [Online 9 April 2003].

63. Weinberg EG. Urbanization and childhood asthma: an African perspective. J Allergy Clin Immunol 2000; 105:224-31.

64. Woodward A, Scheraga JD. 2003. Looking to the future: challenges for scientists studying climate change and health. In: Climate Change and Human Health: Risks and Responses (McMichael AJ, Campbell-Lendrum DH, Corvalan CF, Ebi KL, Githeko A, Scheraga JD, et al., eds). Geneva: World Health Organization; 2003. p. 61-78.

65. Wilkinson P, Campbell-Lendrum DH, Bartlett CL. 2003. Monitoring the health effects of climate change. In: Climate Change and Human Health: Risks and Responses (McMichael AJ, CampbellLendrum DH, Corvalan CF, Ebi KL, Githeko A, Scheraga JD, et al., eds). Geneva: World Health Organization; 2003. p. 204-19.

66. Asher MI, Keil U, Anderson HR, Beasley R, Crane J, Martinez F, et al. International study of asthma and allergies in childhood (ISAAC): rationale and methods. Eur Respir J 1995; 8:483-91.

Article presented in 6/06/2006 